\title{
STRATEGY FOR CHILD CUSTODY SUITS INVOLVING CONFLICT OF LAWS
}

\author{
RAY GRAVES*
}

Suppose $H$ and $W$, married and domiciled in North Carolina, secure a divorce by decree of a North Carolina court and $W$ is awarded custody of the only minor child. $W$ then moves to Virginia and acquires a new domicile there. $H$ now finds that $W$ is living an immoral life in Virginia and desires to secure custody of the child. The question immediately arises: Where may a suit to secure such change of custody be brought, and where will it be more effectivein a Virginia or a North Carolina court? The choice may bear considerably on the length of time it will take, the cost of the litigation, and the number of courts the aggrieved party must go through to reach the desired results. A lawyer with this problem would necessarily direct his thoughts first to the requirements of jurisdiction in suits for custody, keeping in mind that various states follow different jurisdictional rules. These rules are: ${ }^{1}$ (a) that domicile of the child is the sole basis of jurisdiction, (b) that physical presence of the child in the state is necessary, (c) that physical presence of the spouses is sufficient irrespective of where the child is, (d) that jurisdiction, once having attached, is continuing, regardless of the domicile or whereabouts of the parties, and (e) that no hard and fast rule is to be applied, but that any of these bases might serve depending upon the circumstances of the particular case. The last mentioned theory presupposes that, while there may be a concurrent jurisdiction in two or more states, a sound discretion on the part of the courts will be exercised in disposing of the particular case.

Special mention should be made of the last "rule" for it has received closest attention and has gathered a sizeable

\footnotetext{
* 3rd year law student, Duke University; A.B. Washington State CoIlege 1950.

2 See Note, 9 A.L.R.2d 434 (1949).
} 
following over the past few years. ${ }^{2}$ I shall advert to it occasionally for an appraisal of whether it has provided a more satisfactory solution than prior rules.

Since the last significant writing in this field, ${ }^{3}$ an ever increasing number of cases involving some phase of this problem has come before the appellate courts of the several states. This article purports to deal with the end results accomplished by the actual application of one or more of the several bases of jurisdiction to a particular set of facts. Most of the cases that have arisen in the past few years with factual and legal problems allied to those in the hypothetical case have been traced to their ultimate disposition by correspondence with the attorneys in those cases. I propose to analyze the applications of the various rules by answering a series of questions suggested by the cases surveyed. Further the correspondence with the attorneys was had in cases where the child was outside the state of forum; the remainder of the cases are taken directly from the reports.

While the survey indicates that generally lawyers and courts alike are at loss for solutions in particular cases and feel a need for revision in this field of the law, ${ }^{4}$ is has also revealed that wherever practical suits for custody or change of custody should be brought in the state where the child is physically present, regardless of domicile. ${ }^{5}$ In nearly all the cases where suit was brought in a state other than that where the child was physically present and where the decree was adverse to the controlling spouse, such spouse

\footnotetext{
2 See Sampsell v. Superior Court, 32 Cal.2d 763, 197 P.2d 739 (1948); Ex parte Kosh, 233 P.2d 598 (Calif. 1951); Helton v. Crawley, 241 Ia. 296, 41 N.W.2d 60 (1950); Commonwealth ex rel. Camp v. Camp, 150 Pa. Super. 649, 29 A.2d 363 (1942); Finlay v. Finlay, 240 N.Y. 429, 148 N.E. 624 (1925).

${ }^{3}$ Stansbury, Custody and Maintenance Law Across State Lines, 10 Law. \& Contemp. Prob. $\$ 19$ (1944).

4 In Daugherty v. Nelson, 234 S.W.2d 353 (Mo. App. 1950) the court said: "Several theories have been developed to determine the correct basis of jurisdiction to award custody of a minor child, as a conse. quence the cases dealing with the question are in considerable confusion."

- The exceptions to this proposition are those cases where the controlling spouse is in the state and can be effectively controlled. See discussion, infra p. 18.
} 
refused to voluntarily return the child to the party awarded custody. ${ }^{B}$ This fact has generally resulted in resort to the courts of a second or third state by the winning spouse, ${ }^{7}$ a compromise between the spouses, ${ }^{8}$ or resort to selp-help to secure the child. ${ }^{9}$ Often of course financial considerations have prevented any further action. ${ }^{10}$

Aside from the constitutional problem involved in assuming jurisdiction without the domicile of the child being in the state of the forum, sound argument can be made for the assumption of jurisdiction on the basis of physical presence. The court has the child before it and can render an effective decree; often the state in which the child is physically present will have a greater interest in the welfare of the child and the preservation of the family unit than the state in which the child is technically domiciled. Further, as has been indicated, the parties most often find it necessary in the end to resort to the courts of such state regardless of where the original action was brought. So direct move into those courts will often save the client money as well as prolonged litigation. As between physical presence and

\footnotetext{
- Little v. Little, 249 Ala. 144, 30 So.2d 386 (1947) ; Roberts V. Robert's, $300 \mathrm{Ky} .454,189$ S.W.2d 691 (1945); Conley v. Conley, 324 Mass. 530, 87 N.I.2d 153 (1949); Beckmann v. Beckmann, 358 Mo. 1029, 218 S.W.2d 566 (1949); Hughes v. Hughes, 180 Ore. 575, 178 P.2d 170 (1947); Commonwealth ex rel. Camp v. Camp, 150 Pa.Super. 649, 29 A.2d 363 (1942) (the child returned but afterward taken and not since found); Clothier v. Clothier, 232 S.W.2d 363 (Tenn. 1950); Mills v. Howard, 228 S.W.2d 906 (Tex. 1950) ; Peacock $\nabla$. Bradshaw, 145 Tex. 68, 194 S.W. 2d 551 (1946); Kern v. Linsey, 182 Va. 775, 30 S.E. 2d 707 (1944); Clifton v. Clifton [1949] 1 D.L.R. 597 (Br. Col.). In a few cases the child must bave been returned voluntarily, but special circumstances may account for this. Coats v. Coats, 161 Kan. 307, 167 P.2d 290 (1946); Lotz v. Lotz, 327 Mich. 577, 42 N.W.2d 745 (1950) (child to be returned from California in July each year to Michigan-H to pay expenses for $W$ and child). Information has been obtained in part from attorneys in the above cases.

7 Hughes v. Hughes, supra, note 6; Little v. Little, supra, note 6; Boor v. Boor, 241 Ia. 973,43 N.W.2d 155 (1950), to cite only a few.

s Clothier v. Clothier, supra, note 6; Peacock v. Bradshaw, supra, note 6.

- Commonwealth ex rel. Camp v. Camp, supra, note 6 (parties armed only with letter from judge); Mills v. Howard, supra note 6; Clifton $\nabla$. Clifton, supra, note 6.

10 Conley v. Conley, 324 Mass. 530, 87 N.E.2d 153 (1949) (1tr from attorney L. H. Miller, Brockton, Mass.)
} 
domicile as a sole choice for jurisdictional grounds (where the two do not concur), it is thought the better argument can generally be made in favor of physical presence.

For a closer view, the results of the survey have been divided into the particular problems presented. The division is necessarily somewhat artificial since the problems overlap to varying degrees.

r. What are the results when a court accepts jurisdiction on the ground of domicile when the child is out of the state?

In Sampsell v. Superior Court, ${ }^{11} \mathrm{H}, \mathrm{W}$ and child lived in Los Angeles county until 1946 when $W$ and child went to Nevada. $W$ there obtained a divorce and was awarded custody of the child in 1947. She then moved to Utah and was there remarried. $\mathrm{H}$ in the meantime had petitioned the Los Angeles county court for divorce and custody of the child claiming inter alia that $W$ had secured divorce in Nevada by fraudulently representing that she was domiciled there. ${ }^{12}$ Respondent court refused to proceed, basing its refusal on jurisdictional grounds. Upon H's petition, a mandamus was issued ordering the exercise of jurisdiction as to the custody on the ground that physical presence of the child was not necessary and that following the "concurrent jurisdiction" view, the court might take jurisdiction on the basis of domicile. Prior to the decision by the California Supreme Court, $H$ filed suit in a Utah county court and was awarded custody during the summer months of each year. On appeal the decision was affirmed by the Utah Supreme Court.13

Following the view adopted by the California Supreme Court, $\mathrm{H}$ might have brought suit in any of three statesCalifornia, as the state of domicile; Nevada, which had a continuing jurisdiction (assuming it originally had juris-

II 32 Cal.2d 763, 197 P.2d 739 (1948).

12 The California court determined both were domiciled in California.

${ }^{13}$ Sampsell v. Holt, 202 P.2d 550 (Utah 1949). But the court rejected the idea that the lower court could modify the Nevada decree and pre. ferred to rest its affirmance on "changed circumstances"-here passage of time. Proceedings on the mandamus to the Los Angeles county court were dismissed after this decision. 
diction) ; and Utah because the child and controlling spouse were physically present there. In fact $\mathrm{H}$ did go through the chain of courts in two states. ${ }^{14}$

On the surface, it appears H's lawyers would have been wise to resort directly to the Utah courts. The question then is: What advantage, if any, lies in bringing suit in either of the other two states? The case suggests three possible answers: (1) a decree of a Califormia or Nevada court of recent date might have been a powerful weapon in the hands of the plaintiff in the Utah courts; ${ }^{15}(2)$ by this delayed action in arriving at the court of final disposition $\mathrm{H}$ has secured a passage of time which may supply the needed "change of circumstances"; and (3) a suit in the California courts might be more convenient from both a working and financial standpoint.

As to the second answer, the further question suggests itself: Why bring suit to gain passage of time when nonaction might achieve the same result? Several answers might be given, viz. that it is action that may satisfy the client (he knows his lawyer is doing something), and at the same time there is a possible chance of a decree in the plaintiff's favor. As between the home court and a foreign court, the former is more likely to favor the plaintiff..$^{16}$ Then too, the defendant occasionally returns the child voluntarily.

While the plaintiff in the Sampsell case succeeded in securing a change in a previous award of custody, would the

1t It is suggested $H$ would also have gone through the Nevada courts and at least one more California court if suit had not been filed in Utah when it was, unless upon the first award of custody $W$ voluntarily returned the child to $H$. This is rarely the case. The reason for the suggestion is that neither California or Nevada would have been able to enforce their decrees in Utah. For frank admissions that such decrees are unenforceable see: Weber v. Weber, 10 Alaska 214 (1942) and Peacock v. Bradshaw, supra, note 6.

${ }_{15}$ Since full faith and credit may be given. If the decree is not of recent date there will have been time for changed circumstances to have taken place. In Moloney v. Moloney, 167 Kan. 444, 206 P.2d 1076 (1949) twenty-four days was sufficient time for changed circumstances.

${ }^{10}$ That this is often the case, see: In re Brown, 90 Cal.App.2d 651, 203 P.2d 799 (1949) where the parties brought suits in different states at approximately the same time and both received awards of custody. 
same strategy be desirable in a case where a decree of custody is sought for the first time? In this respect consider Beckman v. Beckman. ${ }^{17}$ In that case $\mathrm{H}$ suddenly and unexpectedly departed Missouri, the state of domicile, taking the children with him and settled down in California. $W$ sued for divorce and custody in Missouri. $H$ appeared only specially to contest the jurisdiction. The court awarded custody to $W$, and the decree was affirmed by the Missouri Supreme Court. Nevertheless, $W$ did not get the children for $H$ refused to send them back. $W$ has not pursued here remedies in the California courts. The final result suggests $W$ has gained little by the Missouri decree and its affirmance; further prosecution is necessary for effective results. Perhaps the more effective way would have been for $W$ to bring habeas corpus in a California court immediately following the Missouri lower court's decree ; $^{18}$ if not direct resort to the California courts in the first instance. If the direct method had been used and suit brought before $H$ had a chance to settle down, such suit might have resulted in a decree for plaintiff because of the circumstances under which the children were taken. ${ }^{10}$ If the problem is a financial one this would certainly be the best step and plaintiff can defend in forma pauperis if the defendant appeals the first decree. $^{20}$ Possibly then, while in the Sampsell type case (where one party has already been awarded custody) resort to the state of domicile may sometimes be desirable, it may be disastrous in such cases as Beckman for financial or other

\footnotetext{
17358 Mo. 1029, 218 S.W.2d 566 (1949).

${ }^{18}$ This was the method used in Hughes $v$. Hughes, supra, note 6, and Little v. Little, supra, note 6.

10 Crocker v. Crocker, 219 P.2d 311 (Colo. 1950). But of. Helton v. Crawley 241 Ia. 290, 41 N.W.2d 60 (1950).

$\approx$ Some states so provide by statute. UTAH Cone ANNo. 1943, §28-7-3, reads: "Any person may institute, prosecute, defend, and appeal any cause in any court in this state by taking and subscribing, before any officer authorized to administer an oath, the following . ...". \$28-7-4 provides that no fees shall be paid. Probably no statute is needed and a court may in its discretion order payment of paupers costs. Williams v. Wilkins, 3 Johus Ch. 65 (N.Y. 1817). There is also the posgibility of legal aid. There are many established legal aid clinics in the larger cities as well as committees in state bar orgauizations.
} 
reasons. The recommended strategy would seem to be to prosecute in the courts of the state where the child is no later than after the first award of custody in the home state. This is especially true since where the plaintiff wins in his home court, the defendant will generally appeal on grounds of jurisdiction to secure a passage of time and give the child a chance to get familiar with his new surroundings so that when the plaintiff finally gets to the state where the child is, the defendant can plead "changed circumstances". The method suggested may prevent defendant's strategy from being effective.

It must be emphasized that the above recommendations would not be applicable where the defendant has fled to a state that will not assume jurisdiction except on the basis of domicile. ${ }^{21}$ In these cases the best plan is to secure a decree of custody in the domiciliary state and afterward bring habeas corpus or other proper remedy in the state fled to. A recent case in a state accepting no other basis than domicile indicates the results to be expected. In Allman v. Register, ${ }^{22} \mathrm{H}$ and $W$ were divorced in Henrico County, Virginia, in 1947 and the court then awarded $W$ custody of the child during the school year and to $H$ during the summer months. After the summer of 1950 the father living in North Carolina, refused to return the child to Virginia and $\mathrm{W}$ brought habeas corpus in Mecklenburg County, North Carolina. That court granted a change of custody in H's favor. On appeal the decision was reversed by the Supreme Court because it was said the lower court was without jurisdiction since the child was not domiciled in North Carolina. On remand, the county court, in accordance with the opinion of the Supreme Court, ordered the child returned to its mother in Virginia. ${ }^{23}$

${ }^{21}$ Jurisdiction is used here in the sense of power to make a decree regarding status of the child. This point is well discussed in Stansbury, Oustody and Mraintainence Law Across State Lines, 10 L.\& C.P. 819, 825 (1944).

2233 N.C. 531,64 S.E.2d 861 (1951).

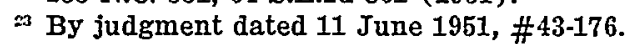


II. What are the results where the suit is brought in a state where one or both spouses are present and the child is absent?

In this type of case, if the court has the controlling spouse before it, measures can be taken to insure return of the child if the decree is adverse to such party. Such measures may include sequestration of the defendant's property in the state, ${ }^{24}$ modification of former alimony decrees, ${ }^{25}$ and requiring the defendant to post a bond to insure return of the child. ${ }^{26}$

If the court in which such action is brought requires physical presence of the child and accepts no other basis, it would seem the court would not take such a case. On the other hand, if the child is domiciled in the state, those courts basing jurisdiction on either domicile, physical presence of the spouses, or the view of "concurrent jurisdiction" would seem to encounter no difficulties.

Often the court has little knowledge of or interest in the child and frankly admits this, yet without too much hesitation proceeds to award custody..$^{27}$ This type of situation occurs where the parties go to another state for a divorce and leave the child behind with friends or relatives. But in many cases the court does have such knowledge and interest, for example cases where the spouses have thought it desirable to take the child out of the state until the marital trouble was over, or purely to escape the effect that is easily predictable of being against them. ${ }^{28}$ Here

24 Turney v. Nooney, 9 N.J.Super. 333, 74 A.2d 356 (1950). See also: Commonwealth ex rel. v. Rahal, 48 Pa. D. \& C. 568 (1937) (attachment. threatened).

$\approx$ Levell v. Levell, 183 Ore. 39, 190 P.2d 527 (1948). See also: Coats v. Coats, 161 Kan. 307, 167 P.2d 290 (1946).

Es Ex parte Halvey, 185 Misc. 52, 55 N.Y.S.2d 761 (1945) affirmed 269 App.Div. 1019, 59 N.Y.S.2d 396 (1945) aff'd sub nous People ex rel. Halvey v. Halvey 295 N.Y. 836, 66 N.E.2d 851 (1946), affirmed on other grounds 330 U.S. 610 (1947).

27 Wilson v. Wilson, 212 P.2d 1066 (Nev. 1949). New York refused to give effect to such a custody award of a Cuban court. Quintana v. Quin. tana, 101 N.Y.S.2d 593 (1950).

${ }_{28}$ See: Commonwealth ex rel. v. Rahal, supra, note 24, and Fagan v. Fagan, 181 Conn. 688, 42 A.2d 41 (1945). 
the court is generally in an advantageous position to force the party to bring the child within the state and when it has taken such action it has been effective.

In the latter type case it would seem the state's interest in the child's welfare is such that the court should make the custody award. This would not be true where it is the spouses who go out of the state rather than the child.

W. What are the results where the child and one or both spouses are out of state but the court accepts jurisdiction because it made the original award of custody and deems itself to have a continuing jurisdiction?

It goes without saying, the problem here is to a large extent like that of taking jurisdiction because of domicile where the child and one of the spouses are out of the state.

A case worthy of examination as indicating likely results is Hughes $v$. Hughes. ${ }^{29}$ In that case $H$ and $W$ were divorced by decree of the Multanomah County Court in Oregon in 1938 and $W$ was then awarded custody of the child. $H$, feeling circumstances had changed, desired to secure custody of the child during the summer months. $H$ was then domiciled in Washington and $W$ in California. The problem is where to file the suit. The temptation is to say California. Under the "concurrent jurisdiction" view either of two would have been proper. In the actual case modification of the decree was sought in the court making the original award and that court granted $H$ part time custody. Defendant appealed, and prior to the final decision by the Supreme Court, plaintiff filed suit in the county in California where the child was. That court adopted the decree of the Oregon court as modified and afterward affirmed. The case suggests that whether one goes to the courts having continuing jurisdiction or not, he will finally end up in the courts of the state where the child is. Even here, the defendant by fieeing to a third state which might also consider itself to

$\cong 180$ Ore. 575,178 P.2d 170 (1947). 
have jurisdiction, may finally win, and often has won ${ }^{30}$ the inevitable result of allowing the child's presence to confer jurisdiction.

Occasionally though, the court has means to effectively control the absent spouse and child. 'Such a case is Levell $v$. Levell, ${ }^{31}$ where the court had originally made an award of alimony to the party given the child and threatened to cut off such alimony unless she heeded the court's orders.

When the spouse granted custody has changed domicile, the new domiciliary state will sometimes deny the jurisdiction of the court claiming continuing jurisdiction and refuse to give extraterritorial effect to any modification by that court. $^{32}$ Only those states recognizing domicile or physical presence of the child as the sole jurisdictional basis would be in this category. Those states taking the "concurrent jurisdiction" view would not be.

Here again, attention should be drawn to the fact that by going to the state having continuing jurisdiction, the plaintiff in the Hughes case secured himself a powerful weapon. Theoretically, the decree in both Oregon and California would have been the same-based on what the child's welfare demanded. Actually the reverse is often true and the plaintiff will get a more favorable reception outside the defendant's home state. ${ }^{33}$ The most undesirable feature is that the plaintiff has secured his weapon in the state which now has the least interest in the welfare of the child.

The court has a more difficult task when plaintiff has secured his "weapon" in the form of a modification by a foreign court. An Ohio court, ${ }^{34}$ while recognizing that the foreign (Belgian) court had acted on the basis of continuing jurisdiction, nevertheless refused to give its decree

\footnotetext{
so Little v. Little, 249 Ala. 144, 30 So.2d 386 (1947) with the final chapter written in Little v. Franklin, 40 So.2d 768 (Fla. 1949) (1tr from Chason \& Stone, Bay Minette, Ala.); Boor v. Boor, 241 Ia. 973, 43 N.W.2d 155 (1950).

31 Supra, note 25.

a McMillin v. McMillin, 114 Colo. 247, 158 P.2d 444 (1945) and Mogs v. Ingram, 246 Ala. 214, 20 So.2d 202 (1944) (ignoring a decree of the Mississippi court made while the child was there).

23 See discussion, supra, note 16.

3* In re Vanderborght, 91 N.E.2d 47 (Cuyahoga Com. Pl.,o. 1950).
} 
effect, because it was said, if service of process in the modification proceedings had been made in Ohio it would have been invalid and have conferred no jurisdiction. It is doubtful if this rationale would stand close analysis for the Belgian court already had continuing jurisdiction and did not need it conferred by service of process. This seems to be the first time the courts have been troubled with such a problem.

IV. What are the results where the child is physically present in the state where proceedings are brought?

Many states, perhaps the numerical majority, will accept physical presence of the child as adequate grounds for jurisdiction. A few regard this as the sole basis. ${ }^{35}$ Many of the results to be expected here have already been indicated, and as suggested earlier, whenever practical suit should ordinarily be brought in the state where the child is physically present. However careful planning on the part of the attorney is necessary. The attorney should try to learn the jurisdictional grounds in the domiciliary state, and in the state where the child is, what weight the latter state will give to decrees of his client's state and to the fact that the defendant fied the first state, and how prone the courts of the second state are to find "changed circumstances".

In those states accepting physical presence of the child as sufficient grounds for assuming jurisdiction, the usual holding is that full faith and credit will be given to the decrees of other states, ${ }^{36}$ and that as to facts occurring before the date of the foreign decree, they are res judicata. ${ }^{87}$ There appears to be a wide split on the last question, some courts holding that such decrees are only res judicata as to facts

s See for example Boor v. Boor, 241 Ia. 973, 43 N.W.2d 155 (1950) (defendant fled two or three days before institution of proceedings in Indiana. The Iowa court said the Indiana court was without jurisdiction to award custody to the plaintiff because the child was in Iowa at the time of judgment).

ca See: Scott v. Scott, 227 Ind. 396, 86 N.E.2d 533 (1949); STUMBEBo, CoNFLict of LAws 327 (2d ed. 1951).

37 McMillin v. McMillin, 114 Colo. 247, 158 P.2d 444 (1945); Lofts v. Lofts, 222 S.W.2d 101 (Mo.App. 1949). 
before the court at the time of judgment. ${ }^{38}$ It would seem if the foreign court so considers its own decrees, then a like consideration would prevail where the child is. ${ }^{30}$ As to facts subsequent to the foreign decree, a determination on the merits is made, and if "changed circumstances" indicate it desirable the court will change the custody. In other words, the mere fact of "concurrent jurisdiction" does not generally mean a redetermination of all the facts.

More complications enter the picture where both spouses file suits in different states at approximately the same time and the courts award custody to opposite parties. In one such case the California Supreme court held ${ }^{40}$ that the decree of the other state (Nevada) would govern because it was made several days earlier, and when Nevada handed down its decree the parties were then divorced and the later California decree of divorce was inoperative, and since the custody award was merely incidental thereto and did not purport to be a modification of the earlier Nevada decree, it would also be ineffective. If those were the real reasons the moral for the attorney might be to file his petition in the court having the shortest docket. Actually, the court was probably adhering to that salutary policy of using the judicial discretion which is part and parcel of the "concurrent jurisdiction" theory adopted in the Sampsell case. A realistic view of the case seems to force the conclusion that California was the state having the greater interest in the family unit and the child's welfare-Nevada's only interest was gained through six weeks residence of the wife in that state. Other things being equal, the tenor of the courts

\footnotetext{
s Ferguson v. Ferguson, 251 Ala. 645, 38 So.2d 853 (1949). The court there said: "Such changed conditions to which the authorities refer is not necessarily confined to subsequent events but may include matter that was discovered though not disclosed when the originai de. cree was entered." Accord: $E x$ parte State ex rcl. McLaughlin, 35 So.2d 507 (Ala. 1948). But cf. Dotsch v. Grimes, 171 P.2d 506 (Cal.App.2d 1946) (holding that a showing of changed circumstances was not nec. essary since the welfare of the child was paramount) and Application of Reed, 152 Nebr. 819, 43 N.W.2d 161 (1950) to same effect.

$\approx$ See Barber v. Barber, 323 U.S. 77 (1944) and Halvey v. Halvey, 330 U.S. 610 (1947).

${ }^{\circ}$ In re Brown, 90 Cal.App.2d 651, 203 P.2d 799 (1949).
} 
opinion seems to indicate it would be in order for $H$ to seek modification of the decree after a reasonable amount of time.

If there are no prior decrees before the court, and the child is present in the state, little trouble is to be anticipated, unless the state is one that rejects all grounds of jurisdiction except domicile.

\section{Problems of "double" and "shifting" domicile.}

Decrees containing part-time custody awards to each of the spouses often give rise to later controversies over the child's domicile. Suppose that $H$, domiciled in Texas, has been awarded custody of the child for three months, and $W$, domiciled in Oklahoma, has been awarded custody the other nine months of each year. Does the child's domicile shift back and forth as the change of custody takes place, i.e. does he have a "double domicile"? If so, does the domicile change when the child should have been transferred? Such is the holding of some courts.41 The consequence is that when the child is with $H$ in Texas, $H$ can seek a change of custody even though Texas requires domicile for jurisdiction. And though $H$ holds the child longer than the three months period (so that if he wins, he will not have to hunt for the child), $W$ can also bring suit in Oklahoma, though that state also requires domicile, since the child now belongs in Oklahoma. Though this rule is of no importance in a case where the two states will accept jurisdiction on the basis of the child's physical presence, it definitely provides a method of securing a change of custody in the most favorable court where both states require or accept domicile as a basis. But rather than holding the child beyond the custody period and seeking the change when the other parent brings habeas corpus, the petition must be brought within the custody period, else domicile has again shifted. This might have been the strategy in Allman $v$. Register, supra.

Still another situation arises where $H$ and $W$ are domiciled in different states and the controlling spouse dies.

a Mills v. Howard, 228 S.W.2d 906 (Tex. 1950); Ex parte Miller, 201 Okla. 499, 207 P.2d 290 (1949). 
Suppose for example $W$, who has been awarded custody of the child is now domiciled in New Mexico where she lives with her parents, and $H$ is still domiciled in Texas, the state where the original award was made. If $W$ dies, where is the child domiciled? The answer given by one court is, that upon the death of $W$, the child's domicile would automatically shift back to the state of the father's domicile. ${ }^{42}$

In both types of cases one of the two states will generally have a continuing jurisdiction and would not need to depend upon domicile. Yet there is a noticeable lack of discussion of continuing jurisdiction in the cases-probably because the lawyers have not pushed the point.

It might ${ }^{\circ}$ be noted here that the whole jurisdictional problem is not peculiar to the United States and the Canadians at least have fared little better than we. ${ }^{43}$

\section{Conclusions and recommendations.}

The answer to the many problems suggested seems to lie in a narrower and more uniform basis of jurisdiction. It does not seem to be in the expanded concept of "concurrent jurisdiction." The conclusions to be drawn from the present state of the law indicate that that concept calls for a discretion which the courts have not often exercised. In fact it offered little change in the former state of the lawit merely provided that instead of some states recognizing domicile, some physical presence of the child or spouses, all states would recognize all bases. Its end result, if uniformly adopted, would be that fleeing parties would never go into a state that would send them home for lack of jurisdiction. Certainly, if the child's welfare is the paramount consideration, some stability in the law over and above what that concept offers would seem desirable.

${ }^{12}$ Peacock v. Bradshaw, 145 Tex. 68, 194 S.W.2d 551 (1946); Note, 136 A.L.R. 914 (1942).

43 Clifton v. Clifton [1949] 1 D.L.R. 597 (the court awarded H custody of the child who was domiciled in British Columbia but living in Alberta with its mother. $H$ secured the child by self-help after $W$ refused to return him voluntarily). But of. Cleaver v. Cleaver [1949] 4 D.L.R. 367, where the Ontario court refused to take jurisdiction where the child was out of the province. McKee v. McKee [1951] 1 All Eng. Rep. 942 is the most recent authority for the Canadians. 
It is somewhat doubtful that all the jurisdictional bases presently used are constitutional, and the United States Supreme Court has consistently refused to meet the problem. The task lies with the state legislatures or Congress to provide some sound and uniform basis within the limits of the constitution.

If the basis is to be narrower and more uniform, there are several possibilities; e.g. any one of the several bases used at present might provide the framework for uniform state laws. The federal government might enact legislation of two types: (a) for the enforcement of uniform state laws in the federal courts or (b) for federal rules of law to govern those who use the channels of interstate commerce to flee with children.

If federal legislation is desired, it is thought the best method would be for congress to make the state uniform laws enforceable in the federal courts with provisions for removal. Such an exercise of the federal power could easily be sustained under the commerce clause as within the principle of such cases as In re Rahrer ${ }^{44}$ and Clark Distilling Company v. Western Maryland R. Co. ${ }^{45}$ An act similar to the Webb-Kenyon Act ${ }^{46}$ would be adequate. For cases of "double domicile" where the spouses are domiciled in different states, Congress might well act under the diversity of citizenship provisions of the constitution. ${ }^{47}$ Use of the federal courts under this provision could be accomplished by dropping the statutory jurisdictional sum necessary to institute civil proceedings.

Should Congress desire to enact the rules of law in the first instance, it might also do this as an exercise of the commerce power. ${ }^{48}$ As precedent for the subject matter we might look to the Federal Kidnaping Act.49

If the states are to enact the uniform legislation, then whatever the course of action desired, we must look first

( 140 U.S. 545 (1891).

Is 242 U.S. 311 (1917).

to 37 STat. 699 (1913).

17 U.S. Const. ART. III, \$2.

4 U.S. Const. AnT. I, \$8.

19 18 U.S.C. $\$ 408 \mathrm{a}$ (1934). 
for the possibilities for jurisdictional basis open under the present state of constitutional law.

The only case in which the Supreme Court has given much consideration to the problem is Halvey $v$. Halvey. ${ }^{50}$ The court there expressly left open the question of jurisdiction to award custody. When that case was before the Florida court the child was neither in the state at the time of the decree nor would it appear he was domiciled in Florida, though he was there when proceedings were begun. $\mathrm{Mr}$. Justice Jackson specially concurred on the ground that the Florida court had no jurisdiction to award custody. Mr. Justice Frankfurter, in a special concurring opinion, indicated that he too doubted the jurisdiction of the Florida Court. His words were:

'The child's welfare must be the controlling consideration whenever a court which can actually lay hold of a child is appealed to on behalf of the child. Short of that, a valid custodial decree by Florida could not be set aside simply because a New York court, on independent consideration, has its own view, of what custody would be appropriate."

These words suggest that jurisdiction on grounds of physical presence would be appropriate. Perhaps either domicile or physical presence would satisfy Mr. Justice Frankfurter's views. Because of the considerations involved, it is doubtful the court would require the domicile necessary in divorce cases.

Let us briefly consider which of the possible bases would be most desirable. Would a uniform acceptance of domicile present many situations where its application would run against the welfare of the child or the inherent rights of the parents? Should one of the spouses go to another state with the child before any award of custody was made, the other spouse would proceed in the domiciliary state, and upon securing a decree of custody, would bring a petition for habeas corpus in the second state. Since that state is also applying the domicile rule, it would refuse to hear the

to 330 U.S. 610 (1947). 
case on the merits and order the child returned to the domiciliary state as in Allman v. Register. If the fleeing spouse has lived in the second state long enough to have acquired domicile then the original suit may have to be brought in the second state, depending on whose domicile the child has -H's or W's. Against the rule of domicile it must be said that often the parties cannot be found until a new domicile has been established and there is still the inconvenience of resorting to another state. The problem of ascertaining the state of the child's domicile will be a difficult one. Often the parties will not have lived in the state of domicile for several years and that state actually may have little interest in their welfare. While a uniform basis of domicile would not be a cure-all, it would make it more difficult, not to flee, but to avoid the effects of an adverse decree. At present many courts frankly refuse to give any weight to the fact that a party has fled a second state in violation of a court decree. ${ }^{\text {11 }}$

For reasons already mentioned the wisdom of a uniform adoption of physical presence of the child as the basis is thought to be unsound. The possibilities open to the losing party to flee from state to state until a decree in his favor is obtained are too great. There is however something to be said in favor of this basis. The state will often be able to enforce its decree and in many cases where the child is more than a mere passer-by the court's interest will be greater than that of a court in the domiciliary state.

It is suggested that the adoption of a uniform state law providing for some sort of residence as the basis of jurisdiction would be the most desirable. Call it domicile if you will-with the period of time comparable to Nevada's divorce provisions. Such a basis would require something less than what is ordinarily necessary to establish domicile and yet something more than physical presence. This would satisfy the jurisdictional requirement imposed by the federal constitution unless the state must take jurisdiction when the child is physically present. The situation created

s1 See note 19, supra. 
would be closer to the ideal, for the court where the parties have last spent any amount of time will be considering the problem and as a consequence the court will have before it the facts. A flight a few days prior to institution of proceedings would not defeat jurisdiction; another state would not make a new determination where the flight is after institution of proceedings but would on petition of habeas corpus order the child returned to the state fled. 